City University of New York (CUNY) CUNY Academic Works

\title{
Aligning the Curriculums for College Success: High School and College Library Collaborations
}

Carl R. Andrews

CUNY Bronx Community College

Dickens Saint Hilaire

CUNY Bronx Community College

\section{How does access to this work benefit you? Let us know!}

More information about this work at: https://academicworks.cuny.edu/bx_pubs/62

Discover additional works at: https://academicworks.cuny.edu

This work is made publicly available by the City University of New York (CUNY).

Contact: AcademicWorks@cuny.edu 


\section{Aligning the Curriculums for College Success: High School and College Library Collaborations}

\section{Carl R. Andrews \& Dickens Saint Hilaire}

To cite this article: Carl R. Andrews \& Dickens Saint Hilaire (2019): Aligning the Curriculums for College Success: High School and College Library Collaborations, Community \& Junior College Libraries, DOI: 10.1080/02763915.2018.1558900

To link to this article: https://doi.org/10.1080/02763915.2018.1558900

曲 Published online: 04 Mar 2019.

Submit your article to this journal $[\pi$

View Crossmark data $־$ 


\title{
Aligning the Curriculums for College Success: High School and College Library Collaborations
}

\author{
Carl R. Andrews and Dickens Saint Hilaire \\ Bronx Community College, Library Department, City University of New York, New York City, New \\ York, USA
}

\begin{abstract}
In today's highly competitive global economy, City University of New York (CUNY) graduates need strong critical thinking skills. More New York City students than ever before are applying to college and enrolling into CUNY schools. This is especially the case with high schools throughout the Bronx, a good portion of these schools are feeder schools for Bronx Community College (BCC). Unfortunately, many of the students who matriculate into BCC come un-prepared for college level work, where information literacy skills are essential. A strong body of published scholarly literature discusses the importance of information literacy instruction at the high school level, as it relates to college readiness. In an ideal secondary education system, students receive instruction on how to think critically, how to evaluate information, and how to avoid plagiarism; these are essential skills that are necessary for college academic success. As the library liaison for the BCC First Year Seminar program, I encounter many students who are in need of academic remediation because they lack research skills. In addition to the lack of information literacy skills, we discovered that a substantial number of students who matriculate into BCC come unprepared for the critical thinking required for college level STEM courses.
\end{abstract}

\section{KEYWORDS}

College readiness;

communities of practice; information literacy; libraryteacher collaborations; pedagogy and curriculum

\section{Introduction}

In 2012 a group of librarians from the CUNY and the New York City Department of Education came together to form a project called the New York City DOE/CUNY Library Collaborative. The goal was to implement a pedagogical model to enhance secondary curricula so that high school graduates would enter college with stronger critical thinking, research, and writing skills. The primary objective is to infuse information literacy into the curriculum and to promote teaching collaborations between common core teachers and the librarians that work at their institutions. Professors Carl R. Andrews (Reference \& Instruction Librarian), and Dickens Saint Hilaire (Chemistry) are sharing the work they did to form the Bronx 
Community College Library High School Collaborative, a collaboration between high school and college educators based on the same model as the New York City DOE/CUNY Library Collaborative (2014).

\section{History of the project}

In a White Paper published in 2014, the following was noted: "NYC Department of Education (DOE) is the largest public school system in the United States with 1.1 million students presenting every variation of opportunity and challenge. And NYC's high schools feed the City University of New York System (CUNY) at a high rate: 75\% of freshman students enrolled in CUNY enroll after attending NYC public high schools. CUNY and the NYC high schools well-understand their shared objective to engage and support students to achieve the skills they need to succeed in college. Though the NYC high school graduation rate has been improving, 56\% of all first-time freshman and $79.3 \%$ of students entering CUNY's six community colleges in the fall of 2012 required remedial coursework. Education reform at this level is acutely challenging, as the two institutions cover 302.64 square miles, serve over 1.3 million students, and employ more than 100,000 people." (The New York City DOE/CUNY Library Collaborative: Q3 Bridging the Gap Between High School and College 2014). The initiative speaks to the heart of collaboration, pedagogical professional development, and most prominently, the librarian's role in establishing Communities of Practice within the institutions they serve. "At the core of the model for Community of Practice are two librarians, one from high school and one from college. The librarians are primarily responsible for recruiting the other working group participants. Librarians serve to draw in others from specific communities of practice by providing both resources and planning. Librarians offer information literacy, the Common Core, and other pedagogies such as inquiry learning and Problem Based Learning." (The New York City DOE/CUNY Library Collaborative: Q3 Bridging the Gap Between High School and College 2014).

\section{Methods for the project}

The BCC Library High School Collaborative is a series of workshops that bring together high school and college teaching faculty to re-design secondary curricula by infusing information literacy, research, and critical thinking skills. For this model, the group meets for five, two-hour sessions. The workshops were made up of six participants and were held at the BCC Library. They included high school and college teachers; a documentarian, and a group facilitator to help the workshop run efficiently. The high 
Table 1. Bronx Community College Library High School Collaborative (BCCHSC).

\begin{tabular}{|c|c|c|c|}
\hline BCCHSC Goals & Methodology & Timeframe & Data Analysis \\
\hline $\begin{array}{l}\text { Goal 1: Revise high school } \\
\text { curriculum units to be } \\
\text { more robust to better } \\
\text { prepare high school stu- } \\
\text { dents to meet the more } \\
\text { rigorous demands of col- } \\
\text { lege level research. }\end{array}$ & Document Review & $\begin{array}{l}\text { Spring and Fall 2016, } \\
\text { Spring } 2017 \text { for five two- } \\
\text { hour sessions. }\end{array}$ & $\begin{array}{l}\text { Rubric developed collabora- } \\
\text { tively by BCC/BCC Feeder } \\
\text { High School participants }\end{array}$ \\
\hline $\begin{array}{l}\text { Goal 2: Develop and nur- } \\
\text { ture permanent com- } \\
\text { munities of practice } \\
\text { among Bronx high } \\
\text { school teachers, librar- } \\
\text { ians, college instructors, } \\
\text { and education } \\
\text { administrators }\end{array}$ & $\begin{array}{l}\text { Observations of working } \\
\text { group sessions } \\
\text { Participant Interviews } \\
\text { Participant Surveys }\end{array}$ & $\begin{array}{l}\text { Spring and Fall 2016; } \\
\text { Spring } 2017 \text { for five two } \\
\text { hour sessions each } \\
\text { At the beginning/end of } \\
\text { each working } \\
\text { group iteration }\end{array}$ & $\begin{array}{l}\text { Comparison of outcome } \\
\text { data for H.S. students who } \\
\text { participated in revised cur- } \\
\text { riculum with those who did } \\
\text { not. } \\
\text { Changes in pre-post Likert- } \\
\text { scale responses and open } \\
\text { ended responses }\end{array}$ \\
\hline $\begin{array}{l}\text { Goal 3: Provide a map for } \\
\text { supporting changes in } \\
\text { how high school and } \\
\text { college educators work } \\
\text { together with librarians } \\
\text { as part of Communities } \\
\text { of Practice }\end{array}$ & $\begin{array}{l}\text { Document review: } \\
\text { Working Group Agendas } \\
\text { and Documentarian Notes }\end{array}$ & $\begin{array}{l}\text { Following each workshop } \\
\text { iteration, finalized after the } \\
\text { conclusion of the final cur- } \\
\text { riculum implementation }\end{array}$ & $\begin{array}{l}\text { Content analysis, explore } \\
\text { patterns of responses } \\
\text { Changes in practice over } \\
\text { time - changes in expecta- } \\
\text { tions and curriculum units } \\
\text { over time; develop } \\
\text { "portraits for promis- } \\
\text { ing practices" }\end{array}$ \\
\hline $\begin{array}{l}\text { Goal 4: Highlight the } \\
\text { important role that } \\
\text { librarians play in sup- } \\
\text { porting teachers to } \\
\text { develop rigorous and } \\
\text { robust curriculum units. }\end{array}$ & $\begin{array}{l}\text { Participant surveys } \\
\text { Student surveys }\end{array}$ & $\begin{array}{l}\text { At the end of each work- } \\
\text { shop iteration }\end{array}$ & Content analysis \\
\hline
\end{tabular}

school teachers had to be willing to share their curricular unit with the group, and be open to constructive criticism. She/he does not necessarily have to be a certified teacher, but the candidate should have at least three years of secondary teaching experience, ideally with grades 11 or 12 . For the initial project, our goal was to recruit a high school teacher from one of the STEM (Science, Technology, Engineering, Mathematics) disciplines; since Professor Saint Hilaire is a college Chemistry professor, we aimed to recruit a high school teacher that would complement his expertise, but schedule conflicts forced us to broaden our selection of teachers. The desired teacher could specialize in any of the Common Core subjects: STEM, Social Studies, and English; just as long as they are sharing a curricular unit they are currently implementing, or plan to implement in the following academic year. Professor Saint Hilaire has played the role of the college professor in all three iterations, with two in Social Studies (The Progressive Movement and the American Westward Expansion), and one in Physics; and despite the varied disciplines, the workshop outcomes turned out to be rewarding experiences for both he, and the high school participants. Although we had to make a slight deflection from the original DOE/ CUNY model, the same principles remained in place. The college professor will teach in a subject that compliments the secondary curricular unit. If 
the high school teacher teaches Global History, the college professor ideally will be an instructor in one of the History courses offered at BCC. A visual for the Workshop Model Process is provided in Figure 2. A chart detailing the project's goals, research methodology, timeframe, and data analysis is provided in Table 1.

\section{Literature review}

In selecting articles for this topic we used keyword searches that would generate the most relevant results. The databases utilized to generate the results are part of EBSCO Host and include the following: Academic Search Complete, Education Source, ERIC (the Education Resource Information Center), Humanities Source, Library \& Information Science Source, MAS Ultra - School Edition. The literature reviewed for this topic is specific to the disciplines of: Academic Librarianship, Collaborative Teaching, Communities of Practice, Critical Thinking, Curriculum Development, Higher Education, Information Literacy, Library Science, Pedagogy, and Secondary Education. The articles examined were published in the following scholarly journals: College \& Research Libraries News, Journal of College Science Teaching, Journal Of Research On Libraries \& Young Adults, Journal of The Australian Library \& Information Association, Knowledge Quest, Library \& Information Science Source, Library \& Information Science Source, Portal: Libraries And The Academy, School Library Monthly, School Library Research, Young Adult Library Services, and Young Adult Library Services. A total of 13 articles were examined and were published between 2003 and 2017. All of the themes addressed in the literature are related to college readiness, library science, collaborative teaching, and communities of practice.

As a group, the BCCLHSC aspired to mimic the Community-Based Team method introduced in the article "Bridges to the Future: Teaching Information Literacy Across Standards, Institutions, and the Workforce." The authors provided examples of how librarians from multiple institutions worked to ease the transition from high school to college. The themes addressed in this paper speak to many of the same teaching objectives we aim to implement in our very own classroom settings; inter-disciplinary partnerships are strongly encouraged at Bronx Community College. "Teaching information literacy skills to prepare young adults for the demands of a technologically modern workforce requires collaboration between schools and libraries. (Anderson-Story et al. 2014, p. 16)

Participants in the BCCLHSC were pleased to discover the amount of current literature focused on the role of the librarian in supporting student success. As noted in their paper "Information Literacy and Retention: A 
Case Study of the Value of the Library", the authors discuss a study conducted at Hofstra University. The study addressed topics such as student engagement, information literacy, and college retention. The primary reason why this article stood out to everyone involved in our project is because the authors share practical methods for librarians interested in connecting with students at both the secondary and college level. "It has been argued that having librarian-student relationships embedded within a student's education can positively impact retention. This suggestion has been supported by research that implies that when librarians proactively offer support to students, there is a positive correlation with retention rates." (Catalano and Phillips 2016, p. 4)

Jean Donham, retired professor of school library studies at the University of Northern Iowa, has published several articles on college readiness throughout her tenure. In her article entitled "My Senior Is Your First-Year Student: High School Transition to College" she shares advice for both secondary and post-secondary librarians and teachers. Donham's discussion comes from the standpoint of someone who understands the bureaucratic challenges academic and school librarians experience on a day-to-day. We thought her ideas, although not applicable in every setting, were relevant to the work we do on our own campuses. "College librarians and high school library media specialists have lots to share with one another. Often, we look within our own literature and ask our peers for guidance on the design and delivery of an information literacy program. (Donham 2003, p. 32) Donham also asserts that "High school and college librarians can only be effective in information literacy when they work in collaboration with faculty. Strategies for engaging faculty in collaboration with librarians for information literacy are in some ways unique to each setting and in some ways similar. (Donham 2003, p. 32)

Workplace readiness skills are being infused into undergraduate curricula more than ever before; much of the current literature addresses career readiness. Lesley Farmer, professor at California State University Long Beach shares advice for educators who are responsible for curriculum development at their institutions. The primary work of the BCCLHSC is first and foremost about preparing high school students for college, however, career readiness is just as paramount on our list of objectives. Bronx Community College has an Experiential Learning task force that seeks to align undergraduate curricula with workplace skills. We were intrigued by the ideas shared in Farmer's paper because many of our students are motivated when they are able to connect the classroom to the workplace. "Schools have a mission to prepare students for college/career readiness. That means graduates will be able to enter post-secondary venues ready to take on those new challenges with the learning tools and habits they gained 
in K-12." (Farmer 2016, p. 12) Throughout her discussion, Farmer speaks to the role of secondary librarians and their need to engage in outreach to their local higher education institutions.

Another paper that stood out to us was "Building Success beyond High School with Career-and College-Ready Literacies." Carolyn Foote, district and high school librarian at Westlake High School in Austin, Texas, gave us plenty of reasons to be inspired. Foote very well could have been the school librarian in our project; we could relate to most of the issued touched upon in her paper, from the high school librarian's perspective. And although the Bronx, New York and Austin, Texas are located in different parts of the country, our school districts serve similar demographic populations. We could relate to her ideas about academic achievement, student engagement, library instruction, and teaching partnerships. The value of educators working together in communities of practice to improve academic performance in students is discussed throughout Foote's paper. "Too often high schools send graduates into the world without practical tools that will help them to be successful; In discussions with our Professional Learning Community groups for twelfth-grade instructors, I've discovered that English teachers at the high school level are mostly unfamiliar with the offerings and navigation of current university library sites. So this year, to expand student support, we are planning (at the time of this writing) more-routine spring semester opportunities for students to engage with university-level pathfinders." (Foote 2016, p. 57-58)

In the article "Community Collaboration for Inquiry Success." Cherry Fuller, Gayla Byerly, Donna Kearley, and Lilly Ramin (2014); a group of librarians from Texas, worked together to develop a curriculum that spans the education continuum; they refer to their work as The Partnership for the 21st Century. The work these librarians did inspired us (specifically the librarians in our collaborative) to be more diligent in our goals for the project. "The Partnership for the 21st Century Skills outlines skills students must master to be successful in college, career, and life, including problemsolving skills, critical thinking, collaboration, information and technology literacy, creativity, and flexibility, among others." (Fuller, Cherry, et al. 2014, p. 57)

The work done speaks to many of the high school to college success initiatives implemented in school districts around the country. In an interview published in a 2016 article for Young Adult Library Services, Mamie Eng, Director of the Henry Waldinger Memorial Library in Valley Stream, New York, offers an idea for librarians who are interested in collaborating with community based organizations. This article was appealing because the BCCLHSC was grant funded; in our proposal, we had to justify our budget in detail. Issues addressed throughout the article include the cost of 
implementing a college readiness program and outreach to community based organizations. The role of public libraries developing programs that promote college readiness is discussed. In the interview, Eng also asserts that local banks, local hospital outreach programs, local legal services outreach programs, Chamber of Commerce members, are all potential collaborators. (Young Adult Library Services 2016, p. 19)

Since the work carried out in the BCCLHSC speaks to professional development, we were interested in readings that would support our pedagogical growth as secondary and higher education teachers. Violet Harada, professor of Information \& Library Science at the University of Hawaii in Honolulu, shares her point of view on PD in her article "A Practice-Centered Approach to Professional Development: TeacherLibrarian Collaboration in Capstone Projects." We were impressed with the ideas presented by this author because the librarian as teacher and curriculum developer narrative is constantly evolving. The content shared in this paper is timely, important, and worthy of being shared with our non-library counterparts. "Library educators have recognized the importance of shifting the PD paradigm from an instructor-driven transmission focus to a learner-centered constructivist approach that more closely mirrors how students effectively acquire information literacy (IL) skills." (Harada 2016, p. 2) We were especially impressed with this paper because it offers a list of team-teaching PD objectives; some of which were carried out in the BCCLHSC workshops. We too planned out teaching strategies that addressed student engagement, inquiry based learning, developing a thesis statement, keyword searching, evaluating information sources, and strategies for retrieving data.

In another article entitled "Librarian-Faculty Collaboration on a Library Research Assignment and Module for College Experience Classes" we were introduced to practical suggestions for initiating teacher/librarian collaborations specific to college readiness. "A librarian and faculty member collaborated on creating a library research module for students in the faculty member's college success classes to help them learn the fundamentals of information literacy." (Keyes and Barbier 2013, p. 93)

Educators throughout the K-16 continuum are beginning to understand that Communities of Practice are essential for improving the teaching and learning experience. In her article "Expanding Librarian Roles through a Librarian Initiated and Facilitated Faculty Learning Community." Misa Mi, Associate Professor and Director of Curriculum Evaluation at Oakland University, shares the following in relation to Communities of Practice: "Most of us may belong to a number of communities of practice that are an integral part of our daily work, family, and social lives. By definition, a $\mathrm{CoP}$ is a group of people "who share a concern, a set of problems, or a 
passion about a topic, and who deepen their knowledge and expertise in this area by interacting on an ongoing basis." (Mi 2015, p. 25)

We were encouraged with much of what Mi offered in her article in relation to how the term Community of Practice can be defined. As librarians who work in educational settings, where most of our colleagues are not librarians, yet value and respect our expertise as an essential part of the academic growth of our students, the feeling of belonging to a CoP is unavoidable.

Another reading that impressed our group, as it relates to academic librarians and their participation in Communities of Practice, is "Librarians as Teachers: Forming a Learning and Teaching Community of Practice." Jennifer Osborn, Research Librarian at the University of Adelaide in South Australia discusses the collaborative work done at that campus. We thought the author shared valuable ideas that could easily be applied to our curriculum development and teaching endeavor. As is the case at the University of Adelaide, many of the professional development projects at BCC encourage the creation and development of learning communities, which in most instances come to fruition from the work done in small Communities of Practice. "As liaison librarians embedded in the faculties and disciplines of the University of Adelaide, Learning and Research Services staff are working to significant changes in educational philosophies and practices. In 2016, we formed a Learning and Teaching Community of Practice (CoP), designed to ground our teaching of research skills and digital literacies in current pedagogy and new teaching methodologies. (Osborn 2017, p. 162)

\section{Stripling model of inquiry}

Barbara Stripling, former President of the American Library Association and former Head of the NYCDOE Office of Library Services, developed a teaching and learning model that supports inquiry based learning throughout the K-12 curriculum. The Stripling Model of Inquiry was referenced for all three iterations of the collaborative. We discussed the idea of creating a poster using the concepts displayed in the model. See diagram of model in Figure 3.

In a 2010 article published in School Library Monthly, Stripling discusses her theory on the learning concept: "Based on research about constructivist learning inquiry, I have developed a six-phase model for the inquiry cycle of learning. As can be seen from the model, inquiry is recursive and cyclical, with learners going back and forth between the phases of inquiry to resolve new questions and complexities as they arise. True inquiry should result in new understandings for learners, but not final answers, because during the process, learners should naturally discover new questions and 
intriguing area to pursue in future investigations." (Stripling 2010) The Stripling Model of Inquiry is utilized by school librarians throughout New York City schools today.

Michael Eisenberg, Professor Emeritus and Dean Emeritus at the University of Washington's Information School co-developed the Big6 ${ }^{\mathrm{TM}}$ research model. In a 2008 article published in the DESIDOC (Defence Scientific Information and Documentation Centre) Journal Of Library \& Information Technology, Eisenberg, discusses how the scaffold can be used to help students with the research and writing process: "My own approach, the Big6, is the most widely used model in K-12 education, world-wide (www.big6.com). With six major stages and two sub-stages under each, the Big6 covers the full range of information problem-solving actions. The Big6 is an approach that can be used whenever people are faced with an information problem or with making a decision that is based on information. Students - K-12 through higher education encounter many information problems related to course assignments. However, the Big6 is just as applicable to professional or personal life. (Eisenberg 2008) There is even a published handbook entitled the Big6 ${ }^{T M}$ Research Notebook (ISBN: 9781586832223), this book helps students to organize their research, a very essential skill set for undergraduate research. "The Big6 ${ }^{T M}$ Research Notebook is designed to help your students successfully complete research and report assignments, while learning topics of interest using the Big6 approach. Using this tool, the teacher-librarian can guide students through the research process in less time, with better results, and with less frustration for students. With the Big6 Notebook, the students have a way to organize their thoughts and note their research findings in a helpful and meaningful format." (Berkowitz and Berkowitz 2006) The six steps are: Task Definition; Information Seeking Strategies; Location \& Access; Use of Information; Synthesis; and Evaluation.

\section{A community of practice}

In the book Thinking for a Living: The Coming Age of Knowledge Work, the term Communities of Practice is defined in the following statement: "Communities, as we use the term, are groups of people who work for a common purpose within an organization, or across organizational boundaries. The community is an environment in which work takes place. Such communities are not restricted to a geographical area, but are connected by their common history and work goals." (Megill and Saur 2004, pp. 107119) For the purposes of the Bronx Community College Library High School Collaborative, the shared interests fall under the categories of academic 


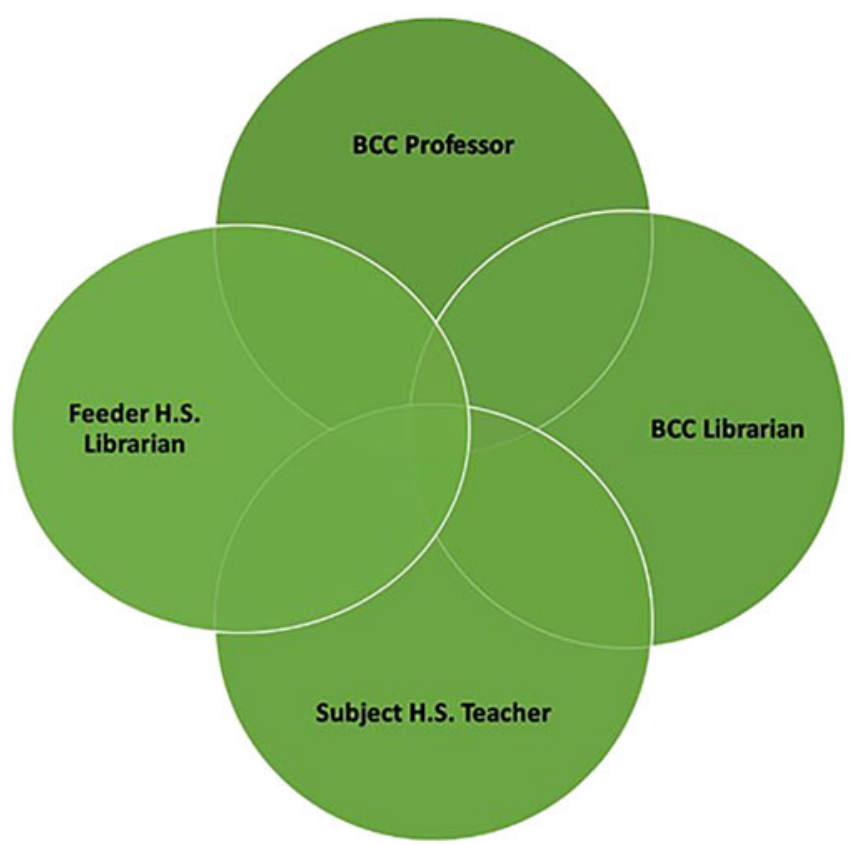

Figure 1. Bronx Community College Library High School Collaborative Model.

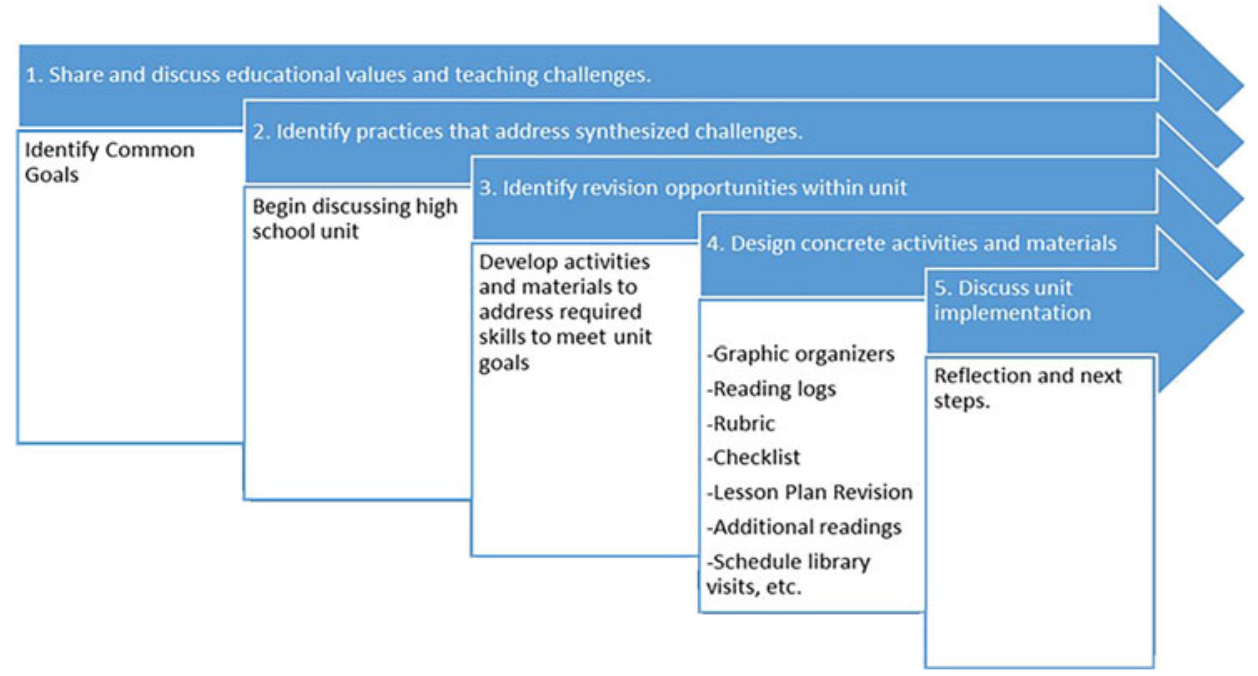

Figure 2. Workshop Model Process - New York City DOE/CUNY Library Collaborative Model.

success in secondary and higher education students; curriculum development, teaching and pedagogy, collaborative learning, and any professional development initiative that promotes the growth and improvement of these interests. The CoP is comprised of the group participants (teachers, librarians, documentarian, and group facilitator), as well as all administrative 


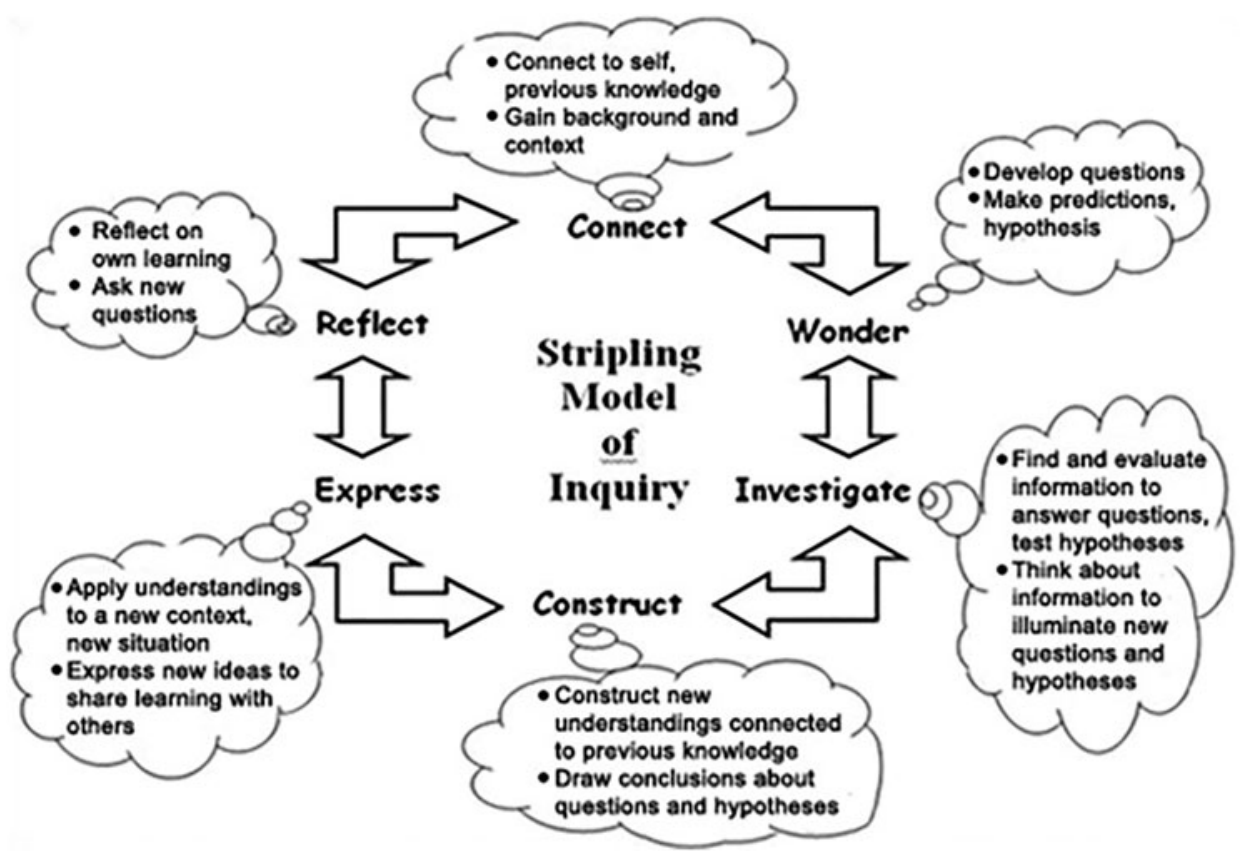

Figure 3. Stripling Model of Inquiry.

entities, including the committees involved in approving the grants that funded the project. A visual interpretation of the CoP model we implemented at BCC is displayed in Figure 1.

\section{The study}

\section{Recruiting the participants}

Recruiting participants for the BCCLHSC wasn't difficult, most teachers (high school and college) generally have an interest in supporting academic success in the students they work with. At BCC, outreach and collaboration are supported by the school's administration, so we were lucky to have administrative support all throughout the project.

We were responsible for drafting the announcements to recruit, a documentarian, a group facilitator, and the high school educators. we reached out to the Bronx Community College teaching faculty, specifically the Education and Academic Literacy Department, for our group Facilitator; we reached out to the English department for our Documentarian; and multiple academic departments for the candidate who would fill the role of the College Professor. We had three different Facilitators for the three iterations of the project, and all three required extensive marketing. Professor Sharmila Mukherjee of the BCC English department became the group's Documentarian, and we are deeply grateful for the work she has done for 
us. To recruit the high school participants, we reached out to the school librarians first, and they in turn would recruit interested teachers from their respective campuses.

\section{Compensation and grants}

Professor Saint Hilaire and I were fortunate enough to have acquired two grants to fund the BCCLHSC, which combined, totaled \$11155.00; the awards were dispersed over three semesters. The group members were compensated for ten hours according to their expertise and the role they played in the collaborative. The DOE high school teachers and librarians were paid $\$ 50.00$ per hour; the group Facilitators were paid $\$ 65.00$ per hour; and the Documentarian was paid $\$ 25.00$ per hour. Professor Saint Hilaire and I did not receive compensation since the workshops took place during our normal working hours. We also purchased supplies from Staples $^{\mathrm{TM}}$ in the amount of $\$ 559.00$, which lasted for all three iterations, and refreshments (coffee, bottled water, and cookies), for \$222.00 each iteration. We do plan on applying for other grants in the future, but would like to try implementing the model without grant funds. Most of the participants are genuinely interested in supporting college readiness and the work done is considered professional development for community college educators and secondary common core teachers.

\section{Anticipations and standards}

\section{Learning outcomes for students at secondary level}

The American Association of School Librarians (AASL) has promulgated a set of standards that anticipate the learning outcomes for students at the secondary level (AASL, 20 Inquire, think critically, and gain knowledge; draw conclusions, make informed decisions, apply knowledge to new situations, and create new knowledge; share knowledge and participate ethically and productively as members of our democratic society; and pursue personal and esthetic growth.

\section{Anticipated outcomes for BCC freshmen}

The Bronx Community College Library developed a brochure to market information literacy concepts to students and faculty. THINQ is an acronym for Topic, Hunt, Information evaluation, New Knowledge, and Quote. The brochure is the Library's brand and is shared with students and faculty at BCC. Students are encouraged to use the brochure as a reference tool for their research and writing assignments. Teaching faculty are encouraged 
to use the brochure to infuse information literacy skills into their courses. We used the THINQ brochure for each iteration of the BCCLHSC; when high school classes visit the BCC Library for their introduction to college research, the brochure is distributed to familiarize the students with the IL performance indicators.

\section{Standards and frameworks for higher education}

The Association of College \& Research Libraries (ACRL), a division of the American Library Association, is the professional association for academic librarians. The Information Literacy standards that librarians have used to support higher education curricula were established and implemented through ACRL. As of February 2, 2015 ACRL adopted, what has come to be known as the Framework for Information Literacy for Higher Education. Unlike the Information Literacy Standards for Higher Education, the Framework is more fluid, giving us more options for disseminating information literacy content; for academic librarians, it means adapting our teaching methods. College librarians are no longer just the gatekeepers of information; they are increasingly tasked with engaging students in the classroom, just as subject faculty. For the purposes of our work with the BCCLHSC, the goal is to align the AASL Standards with the ACRL Framework so that our students leave high school and enter college with stronger research skills.

The six concepts that anchor the frames are as follows: 1. Authority Is Constructed and Contextual (ACRL, 2016) 2. Information Creation as a Process (ACRL, 2016) 3. Information Has Value (ACRL, 2016) 4. Research as Inquiry (ACRL, 2016) 5. Scholarship as Conversation (ACRL, 2016) 6. Searching as Strategic Exploration (ACRL, 2016).

\section{Curricular units}

The curricular units revised throughout the collaborative all offered plenty of opportunities to increase student research and library collaborations. The first unit presented was developed for a $12^{\text {th }}$ grade American History class and was entitled Lessons for the Progressive Movement. Among the list of assignments included, one required students to evaluate the roles of prominent social reformers from 1880-1912. We recommended literary reviews of primary sources retrieved from Infobase. We shared a number of biographical encyclopedia articles of prominent African Americans and Women. All of the recommended content addressed themes related to: Social Reform; Education; Women's Suffrage; Social Gospel; Labor Reform; Immigration and Eugenics; Political Corruption; Conservation; Political 
Reform; African American Rights; and Economics. The group brainstormed ideas on how to engage students by using CQ Researcher reports with progressive themes like the "Occupy' Movement", "Living-Wage Movement" "Fighting Urban Poverty"; and "Human Rights". After introducing the recommended resources to enhance his unit, the teacher suggested having students use the CQ Researcher reports as a model for them to create their own Progressive Movement report. Creating a report similar to the ones indexed in CQ Researcher requires math, writing, art, reading, and research.

The second unit presented to the collaborative was developed for a $9^{\text {th }}$ grade Physics class; the unit was entitled University Heights High School: Ninth Grade History of Engineering and Inquiry. There was concern about the grade level, but the group worked with the theory that college readiness can begin as early as the Primary level. We had fun brainstorming ideas to enhance this unit. Professor Saint Hilaire was heavily engaged since his specialty is Chemistry; Chemistry and Physics deal with the behavior of matter. The unit was aimed at enabling students to conceptualize "models." The core concepts of engineering like precision and conservation of energy and momentum that are required to be built into mathematical models would help students answer the following questions: How do scientists create models? How can learners develop and use mathematical models and diagrams to describe and predict the motion of an object? And lastly, can there ever be an absence of energy?

The third and final unit for the collaborative was developed for $11^{\text {th }}$ grade Social Studies and was entitled American History of Social Justice Unit 3- Westward Expansion. This was an especially emotional unit to revise, because the teacher wanted to engage her students by analyzing the Trump Presidency and his controversial statements about Mexican Americans and Muslims. For this unit, we reached out to one of the History professors at BCC and requested he share his course syllabus with us. The syllabus was used as a teaching tool to give high school students an idea of what to expect upon enter college. In addition to the BCC History syllabus we scanned and printed out graphs and charts from Infobase. The recommended research topics for this unit were Manifest Destiny; Native American Territory Losses; Growth of the Railroads (1850-1860); The Louisiana Purchase; California Gold Rush 1848-57; Trail of Tears; Indian Reservations in the Midwest, 1840; Transfer of Indian Land, 1850; Western Expansion of the United States, 1787-1867; and the Chinese Exclusion Act. The group brainstormed and proposed developing research assignments about "Police Brutality" throughout the country. Students would be tasked to visit the U.S. Department of Justice web page to retrieve statistical data on police 
misconduct throughout the United States; they would then schedule a day and time to visit a police precinct in their neighborhood to interview a law enforcement official. The issue of "Gentrification" was also discussed in this unit, group members associated the term with modern day "Ethnic Cleansing".

The group also discussed two resources the teacher used for her class: the Stanford History Education Group and the Debating US History Curriculum Project; this is a CUNY College Readiness initiative, once users create an account they have access to lessons, PowerPoint presentations, primary sources, quizzes, and a host of other tools to enhance instruction. (Copies of the curricular units can be obtained from the authors)

\section{Library resources used}

The resources used throughout the BCCLHSC were selected for their ability to scaffold critical thinking and inquiry based learning. In theory, most students are visual learners; in all three iterations of the project, participants agreed that graphic organizers and visuals were excellent tools to use for teaching concepts in both science and social studies. These teaching resources are used until the students have mastered the basic steps required for the research process. The high school librarian and I used a collection of resources to enhance the curricular units. Starting with the NYCDOE's Office of Library Services, the resources supplied by this office were developed to support information literacy instruction and library/teacher collaborations.

\section{Electronic resources}

For our project, the use of electronic resources made sharing content with the high school participants easier. In today's library (school, academic, and public), research databases are varied and abundant. For the purposes of our work, we chose databases we thought were best suited for secondary and post-secondary research. Most research databases are created to support teaching and learning, but not all are ideal for information literacy instruction. JSTOR, for example, is an excellent database with strong scholarly content, however, JSTOR assumes the user has prior knowledge with academic research and is familiar with the scholarly communications process. The BCC Library, the New York Public Library, and New York Online Virtual Electronic Library (NOVEL) are the access points for the databases referenced throughout the collaborative. In the interest of supporting college readiness in secondary and undergraduate students, the participants in the collaborative felt it was best to utilize databases with the following "college readiness" attributes: 
- supports language and literacy development in secondary and undergraduate students

- provides scaffolds that support critical thinking and inquiry based learning

- contains tools to help students with the writing process

- contains tools to help students with citation and avoiding plagiarism

- $\quad$ provides multi-media, images, maps, charts, graphs, and timelines

For all three iterations, the librarians in the group extracted curriculum supporting content from each of the access points and databases listed below. For our project, the recommended resources support teaching, learning, and research related to the Progressive Era, Physics and Engineering, and the Westward Expansion.

New York Online Virtual Electronic Library (NOVEL); NOVEL is a free online resource developed by the New York State Library (a division of the New York State Education Department) for schools in New York State that do not have libraries.

The New York Public Library is another free resource available to high school students and their teachers. The number of NYPL's online resources surpass what is available through NOVEL, but if a student misplaces their library card, they can use NOVEL as a backup.

Most academic libraries subscribe to databases designed especially for undergraduate research; some of these databases are appropriate for high school research. NYPL subscribes to more online resources than NOVEL, but as an academic library, BCC Library subscribes to a large selection of online resources not available through NYPL or NOVEL. Long after the workshops have ended, I am able to share scholarly and peer reviewed content, specialized encyclopedia articles, primary sources, and teaching aides that would otherwise not be available to the BCCLHSC participants or their students. The electronic version of World Book has evolved to compliment a multitude of divers learning (and teaching) styles: there's multi-media, hands-on activities, interactive maps and atlases. Learning Express/ PrepSTEP (EBSCO) Is a database that supports both college and career readiness in secondary and post-secondary students.

\section{Research paper organizer}

One of the most essential resources that we used in all three iterations of the BCCLHSC is a Research Paper Organizer. As we have indicated, students are entering college lacking writing and critical thinking skills. The Research Paper Organizer is a graphic organizer, a critical thinking guide, and an information literacy scaffold all in one. Based on a research process 
known as the Big6 ${ }^{\mathrm{TM}}$, the organizer is divided into six distinct sections that guide students through the research and writing process: 1. Task Definition; 2. Information Seeking Strategies; 3. Location \& Access; 4. Use of Information; 5. Synthesis; and 6. Evaluation. I took the Big6 ${ }^{\mathrm{TM}}$ concept and adapted it to be used with our freshmen students at BCC. The BCC Library Research Paper Organizer can be found on my LibGuide under the Information Literacy Tools tab. The great thing about the Big6 ${ }^{\mathrm{TM}}$ is that it can be adapted for any discipline. It is a teaching scaffold was used primarily in K-12 settings, but after my first year working as an academic librarian, I discovered that the Big6 ${ }^{\mathrm{TM}}$, although developed for $\mathrm{K}-12$, could be used with college freshmen. College instructors from multiple disciplines have praised the Research Paper Organizer for its ability to help students to think and write like a scholar. Librarians from K-16 use it because it is based on the model of Bloom's Taxonomy because it promotes metacognition.

\section{Color coded know your information sources}

Most secondary and college librarians will agree that visuals are a great way supplement information literacy instruction; especially since much of jargon we use can be foreign to young adults. This color coded graphic guide, derived from the Big6 ${ }^{\mathrm{TM}}$ collection of information literacy instructional tools, isolates all of the possible information sources into colors, and summarizes the information's type, purpose, and audience. (See Figure 4)

\section{C.R.A.P. Website evaluation checklist}

The C.R.A.P. Website Evaluation Checklist opens the door to plenty of learning opportunities, it is a graphic organizer that teaches students how to think critically and to view information with a skeptical eye. The acronym stands for Currency, Reliability, Authority, and Purpose \& Point of View. Although there are many versions of this teaching scaffold, the C.R.A.P. Website Evaluation Checklist referenced here was created by Elizabeth Dolinger, Information Literacy Librarian, Mason Library Keene State College. The document can be viewed by visiting the Keene State College Library web page at the following URL: http://library.keene.edu/ld. php?content_id=7239431

\section{Project challenges}

\section{Tracking a cohort}

As of now, we rely heavily on the high school participants to remain in touch with me and to keep the lines of communication open between the 


\section{KNOW YOUR INFORMATION SOURCES}
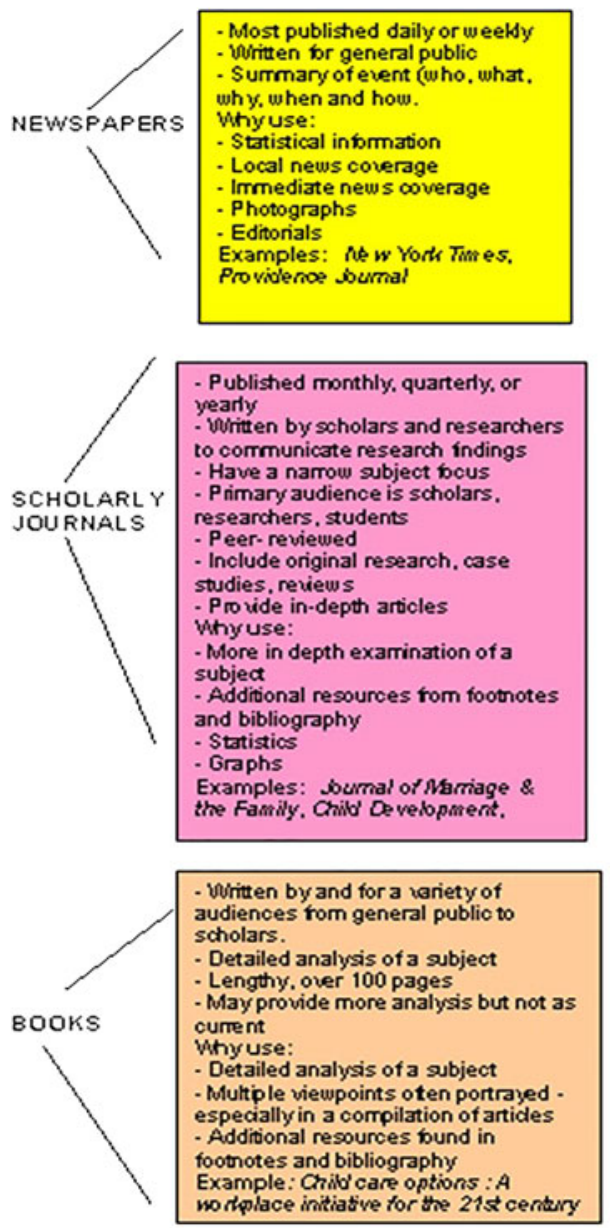
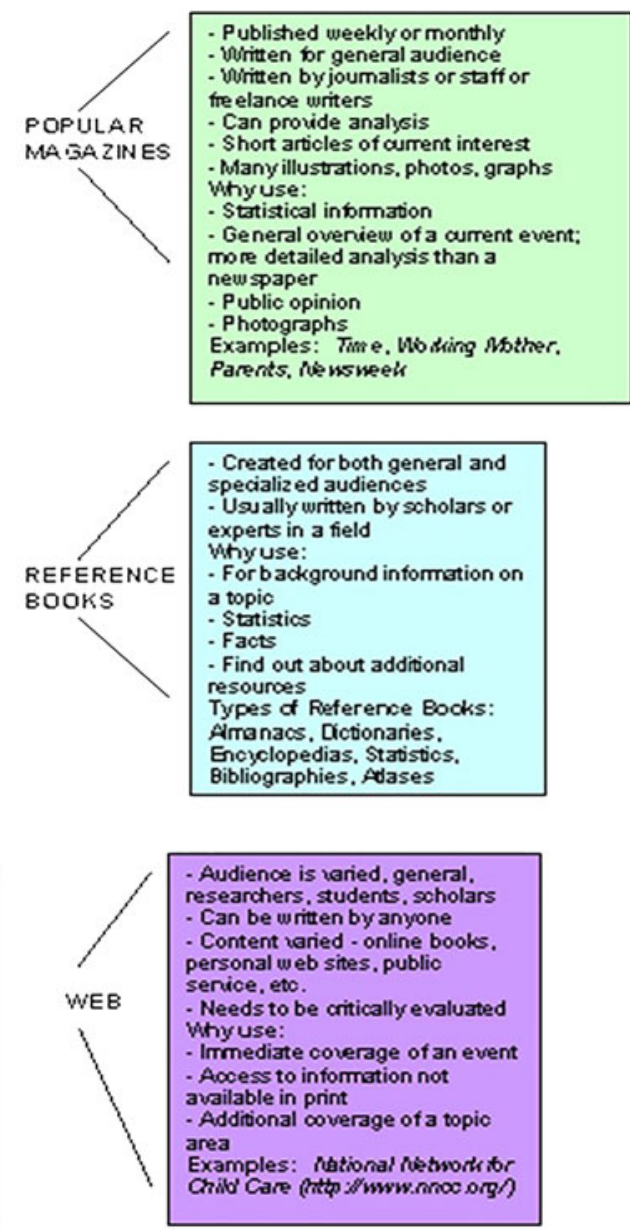

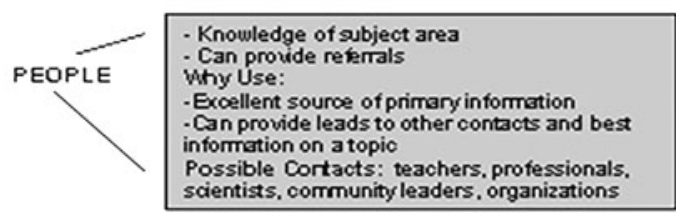

Figure 4. Know Your Information Sources (Eisenberg \& Berkowitz, 2017).

BCC Library and the participant's school. The Social Studies teacher from the first iteration and teacher at the High School For Arts, Imagination And Inquiry (another BCC feeder), follows up every semester by bringing a group of his 12th grade students to the BCC library with a research assignment. Unlike UHHS, the campus librarian who works with him to infuse the recommended scaffolds and readings for his unit on the Progressive Era. He is an ongoing participant of the BCCLHSC; and many of the students who visit BCC on their research field trip, do plan to attend BCC upon graduation. Unfortunately, it is not a guarantee that they will in fact 
matriculate into BCC, and we have no way of tracking the students who graduate from the participating schools. This means we cannot determine if they are entering college with stronger research skills as a result of being exposed to the revised unit. Since the drafting of this paper, there have been a handful of students that we know of who have had exposure to the revised curriculum, but it is still difficult track those students for a number of reasons; sometimes they take a year off before starting college, or they attend another college upon graduating and transfer into BCC two, or three semesters later. We've learned that many of the high school students who were exposed to the revised unit were classified as Advanced Placement; most of them matriculated into four year institutions across the country. When this project is implemented again, we will aim to work with general education students and teachers. We will also develop a more organized plan for tracking the students that we know for certain will matriculate into BCC upon graduating high school. We've begun communicating with guidance counselors and campus librarians and another educational campus that feeds into BCC.

\section{Sustainability and measurability}

Implementing a collaborative that is permanent, sustainable, and measurable is another challenge. The only sure way to do this would be to hire a college librarian designated as the High School Library Liaison. These librarians that work for colleges have high schools attached to the college, in some instances the school is physically on the college's campus. In this case, the students have full access to the library's research databases on and off campus 24/7. The High School Library Liaison's job, to reach out and market the library's services to the high school, is simplified. Compiling statistics on the work she/he does with the students and teachers is easy because they are embedded into the school's curriculum development and design process.

\section{Participant availability}

As noted earlier, we had to select teachers from disciplines other than STEM, specifically Chemistry. When surveyed, both high school teachers and librarians indicated that a college readiness program that focused on Information Literacy was important, and if presented with the opportunity, they would be willing to participate in such a collaborative. The most significant issue with recruiting the participants was their availability; most of the teachers we reached out to were not available after school between the hours of 3:30-5:30pm, and many worked at schools with extended days. 
Table 2. Survey Questions.

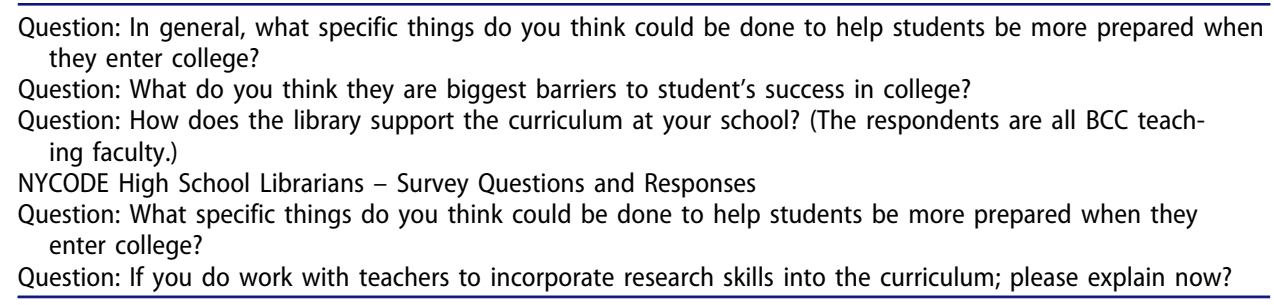

One of our potential candidates went as far as filling out the paperwork, but at the last minute had to decline because of childcare issues.

\section{Surveys}

During the last iteration of the BCCLHSC, Professor Saint Hilaire and I administered three surveys to gauge our colleague's thoughts on the importance of libraries, information literacy instruction, working with our high school/college counterparts, participating in pedagogical communities of practice; and their perceptions on how all of these factors relate to college readiness. The surveys were administered to Bronx Community College teaching faculty, NYCDOE High School Teachers, and NYCDOE High School Librarians. Although the survey for H.S. Teachers was shared via email listserv to dozens of secondary teachers throughout the Bronx, only seven teachers participated; what's more, they (the seven) provided very few answers for the open-ended questions. Forty BCC college faculty, and fifty-two H.S. Librarians participated in our survey. These two groups provided answers for the open-ended questions. We extracted questions from the surveys that required open-ended responses; some of those responses are listed in the charts below. The survey responses speak directly to the important work we are doing at BCC, as well as the works done at other CUNY campuses through the New York City DOE/CUNY Library Collaborative. For full copies of the surveys and their responses, please contact Professor Carl R. Andrews at carl.andrews@bcc.cuny.edu; or Professor Dickens Saint Hilaire at Dickens.St_hilaire@bcc.cuny.edu

\section{Conclusion}

The BCCLHSC has opened the door to further teaching and learning partnerships. Since the spring 2017 iteration, we have been offered the opportunity to collaborate with other college professors who are interested in supporting this college readiness initiative. Professor Saint Hilaire and I look forward to implementing the collaborative in the not too distant future. We are thrilled to have the opportunity to contribute to the 
conversation. We could have extended this workshop out over an entire semester, but we did not have the funding. That is not to say the participants wouldn't have been willing to continue the work, there was great enthusiasm amongst all involved. Recommendations for improving this project include, but are not limited to: expanding the model from five two hour sessions to ten; hire a Project Manager; arrange class visits immediately following workshop iterations; source participants from College Now schools. College Now is a City University of New York and New York City Department of Education program that allows high school students to take college-level classes before they officially begin college.

\section{Funding}

Adding a monetary incentive certainly increased interest in the project, and as we move forward, we will continue to seek out grant opportunities to continue implementing the BCCLHSC. The Documentarian and Facilitator roles require a specific skill set, compensation for these jobs is warranted; although unlikely, some people may enjoy doing the work without being compensated. At CUNY, Faculty (non- Junior tenured) are required to be involved in service activity as part of the tenure-track process, they're constantly looking for opportunities to enhance their CVs, so participation in a project that speaks to college readiness may look attractive to teaching faculty. Recruiting secondary teachers and librarians to do the work for free is another story.

\section{References}

American Library Association. 2015. Framework for Information Literacy for Higher Education. Association of College \& Research Libraries. Chicago, IL: ALA American Library Association. Accessed February 2015. http://www.ala.org/acrl/standards/ ilframework.

Anderson-Story, J. 1., et al. 2014. janderson@fhtc.edu, "Bridges to the future: Teaching information literacy across standards, Institutions, and the workforce." Kansas library association college \& University libraries section proceedings 4, no. 1 (January, 16-26. Library \& Information Science Source

Berkowitz, R. E., and A. Berkowitz. 2006. The Big6 Research Notebook. Worthington, OH: Linworth Pub.

Catalano, AMY. 2016. 1, Amy.Catalano@hofstra.edu, and Sharon R.2, Sharon.R. Phillips@hofstra.edu Phillips. "information literacy and retention: A case study of the value of the library." Evidence Based Library \& Information Practice,. 11, 4. Library \& Information Science Source, University of Alberta, Learning Services. http://ejournals. library.ualberta.ca/index.php/EBLIP

Communities of Practice. 2004. In Thinking for a living: The coming age of knowledge work, ed. K. A. Megill and K. G. Saur, 107-119. https://www.degruyter.com/ 
C.R.A.P. Website Evaluation Checklist. Edited by Elizabeth Dolinger, INFOhio: Ohio's prek-12 digital library., INFOhio Citation Guide: Evaluating Sources, Oct. 2017. https:// docs.google.com/document/d/ 1p3QuWSjTrjmsQ12CnH0g6MMGVxSwPRlmhIYFvUB5KXD fTU/edit

Donham, J. 2003. My senior is your First-Year student: High school transition to college. Knowledge Quest 32(1):32.

Duguid, P. 2018. Communities of practice. In Encyclopedia of Community, ed. K. Christensen and D. Levinson, Vol. 1, 233-236. Thousand Oaks, CA: SAGE Reference, 2003. Accessed January 23, , 2018. http://link.galegroup.com/apps/doc/CX3452300099/ GVRL?u=cuny_bronxcc\&sid=GVRL\&xid=b 3bacd72.

Eisenberg, M. B. 1. 2008. Information literacy: Essential skills for the information age. DESIDOC Journal of Library \& Information Technology 28(2):39-47.

Eisenberg, M. 2017. Know your information sources. The Big6 ${ }^{T M}$ http://big6.com/media/ freestuff/know-your-info-sources.gif.

Farmer, L. 2016. Ready to get students college/Career ready? What's the teacher librarian's role? CSLA Journal 40(1):12-3. Accessed December 6, 2017.

Foote, C. 2016. Building success beyond high school with Career- and College-Ready literacies. Knowledge Quest 44(5):56-60.

Fuller, C., Donna, K., Gayla, B., and Lilly, R. 2014. Community collaboration for inquiry success. Knowledge Quest 43(2):56-59.

Getting Ready for College Life: An Interview with Mamie Eng. 2016. Young Adult Library Services 14(4). Accessed December 6, 2017. http://www.ala.org/yalsa/young-adult-libraryservices\#About\%20YALS

Harada, V. H. 2017. A practice-centered approach to professional development: Teacherlibrarian collaboration in capstone projects. School Library Research 19, 1-47.

Keyes, A., and P. Barbier. 2013. Librarian-Faculty collaboration on a library research assignment and module for college experience classes. Community \& Junior College Libraries 19(3/4):93-103. Accessed December 6, 2017. doi:10.1080/02763915.2014. 949197.

Mi, M. 2015. Expanding librarian roles through a librarian initiated and facilitated faculty learning community. Journal of Library Administration 55(1):24-40. doi:10.1080/ 01930826.2014 .978683 .

Osborn, J. 2017. Librarians as teachers: Forming a learning and teaching community of practice. Journal of the Australian Library \& Information Association 66(2):162-9. doi: $10.1080 / 24750158.2017 .1328633$.

Standards for the 21st-Century Learner. 2007. American association of school librarians (AASL). Chicago IL: USA., American Library Association. Accessed December 20, 2018. http://www.ala.org/aasl/standards/learning.

Stripling, B. 2010. Teaching students to think in the digital environment: Digital literacy and digital inquiry. School Library Monthly 26(8):16-9.

The New York City DOE/CUNY Library Collaborative: Bridging the Gap Between High School and College. Gale Cengage Learning. 2014. Accessed April 2015. https://blog.cengage.com/new-york-city-doecuny-library-collaborative-bridging-gap-high-school-college/ 